\title{
Outdoor Pottery Sculpture in Ife Art School
}

\author{
Moses Akintunde Akintonde ${ }^{1}$ \\ Toyin Emmanuel Akinde2 \\ Segun Oladapo Abiodun ${ }^{3}$ \\ Michael Adeyinka Okunade 4
}

\begin{abstract}
1,2,3 Department of Fine and Applied Arts, Ladoke Akintola University of Technology, Ogbomoso, Nigeria ${ }^{4}$ Department of Fine Arts, Obafemi Awolowo University, Ile-Ife, Nigeria; ${ }^{1}$ maakintonde@lautech.edu.ng 2teakinde@lautech.edu.ng, 3bishopsegunabiodun@gmail.com, ${ }^{4}$ okunadeadeyinka@yahoo.com
\end{abstract}

\section{Doi:10.5901/ajis.2015.v4n3p219}

\begin{abstract}
The rich public outdoor sculpture practice of the Southwest of Nigeria still lacks scientific and empirical experimentation of nonconventional material for the production of outdoor sculpture, particularly pottery images. Although scholarship on public outdoor sculpture in the Southwest of Nigeria is becoming steady in growth, yet a reconnaissance study of the pottery sculpture in art practice and historical perspective has not been made. A study of this type of art, erected in the garden of Ife art school is exigent and paramount now that many of the works are not being maintained. The study underscores the inherent values in the genre of the art; and examined pottery sculpture types, its uses in public sphere and its development in morphology, iconic thematic and stylistic expressions. The study observed that outdoor pottery sculptures are impressive, apparent in sculpture multiplicity of type and dynamics; it is rare in occurrence in Southwestern Nigeria.
\end{abstract}

Keywords: Ife Art School; outdoor sculpture, pottery sculpture; handbuilt pottery; Yoruba pottery.

\section{Introduction}

The praxes of outdoor sculpture in Nigeria, beginning from the first quarter of twentieth century presented different latitudes. Over time the art developed rich genre of high conceptual contemplations; form, style, themes, techniques and material handling became impulsively complex and alluring. Nonetheless, as prodigious as the art in the use of conventional media, exploration of non-conventional media is largely lacking in empirical and experimental practices; unlike the Western world, where varieties of media such as metal art objects in bronze, wrought or welded iron are abound. Stone, glass, fibre cast, fundu and even terracotta sculpture objects have been freely used. In Nigeria, and Southwest in particular, apart from marble and rarefied bronze sculpture found in cemeteries and individual homes, cement medium was in general use in the public sphere (Akintonde 2009a: 95-108 and 2013a: 120-129). Polyesther resin not commonly use, only came into public outdoor sculpture dialects in the early part of 1980's and it was not immediately deployed primarily for lack of technical handling and high cost.

A type of sculpture that has not been ascribed any importance in public outdoor sculpture practice in Southwest of Nigeria is pottery sculpture. Although, numerous exquisite pottery sculptures had been found in Nok area of Jos (plates 1), Ile-Ife, Owo, Afigiokwu and a few other places in Nigerian, they were invariably associated with religious objects kept in shrines and groves in the ancient time (Fagg 1990: 1-40). Such terracotta figure sculptures are still presently used in the shrines in the Southern part of Nigeria. Yet, its potency in expression and values has not received attention in the practice of contemporary public outdoor sculpture in the country, particularly in the Southwestern zone. In the entire Southwestern Nigeria today, apart from the works of Adepelu (plates 2), a traditional potter in Igbara Odo in Ekiti State and few other works from Erusu, Isua-Ekiti and Yewa, there are no other pottery centres that may be associated with pottery sculpture production. However, where pottery sculpture is practiced basically for ritual purpose, its production and use are always cryptic and esoteric (Akintonde, 2009a: 95-108). 

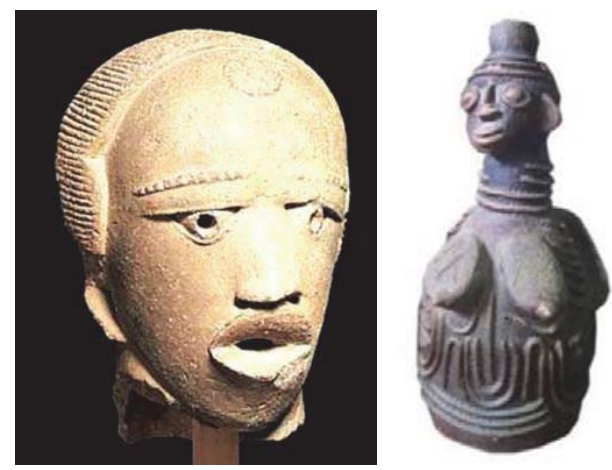

Plate 1: Nok Head, 500 B. C. - A. D. 200, Terracotta, Jemaa, Nigeria. Courtesy: Fagg, 1990

Plate 2: Felicia Adepelu, Abiyamo, Terracotta, Igbara-Odo Ekiti. Photograph by Segun Abiodun, 2015

In the formal art school, few students who usually specialise in ceramics, very negligible numbers of them often show dexterity in pottery sculpture production. In fact, by 1980 no other art school apart from Ife produced monumental pottery sculpture in Nigeria. Nonetheless, there was evidence of off-shoot of monumental pottery sculpture in some of the Southwestern Nigeria tertiary institutions where Ife art school products lecture. Art schools such as Ikere Ekiti College of Education, Ekiti State as well as Osun State College of Education, Ila-Orangun, Osun State started producing monumental pottery sculpture by the mid-eighties. The practice started in Ladoke Akintola University of Technology Ogbomoso, Oyo State in 1994 and rose to prominence; taking the lead from Ife art school by 2000. Other art schools in Nigeria concentrate more on industrial ceramic production orientation than hand built pottery. Studio artists and ceramic industries across the nation also only produce ceramic sculpture minimally. In the schools where pottery sculptures were produced, the use was mostly limited to interior decoration. This factor may have been responsible partly for the nonusage of pottery sculpture in the public environment of the Southwestern Nigeria, despite its justified possibilities and versatility compared to other media. The only notable public environment where outdoor pottery sculptures have been used even till now is the Department of Fine Arts Sculpture Garden in Obafemi Awolowo University, Ile-lfe.

Ife art school being renowned for production of profusely decorated monumental pots with pottery sculpture high index used for both indoor and outdoor environments yielded richly art historical discussion in the contemporary Nigerian art. This is also pertinent enough and germane to art development. Yet, the art has not been critically studied. Studies made on the art school are few and too general in their discourse even, those that centered on pottery production in the Art School (Fajuigbe and Umoru-Oke, 2005: 24-46, Akintonde, 2013b: 136-144 and Ajadi, 2014) did not identify outdoor pottery sculpture value and uses. In view of the foregoing, there is significant art historical gap in the history of the Art Schools in Nigeria and invariably Nigerian contemporary art.

This study examined the pottery sculptures of Ife art school generally and basically its uses for outdoor sculpture in the institution and linked with outdoor sculpture in Southwestern Nigerian public space. The study became necessary now, because the pottery sculpture were no longer maintained properly. Many of them have been badly damaged, while some have been lost totally. Yet, the school did not keep records of students' works which could have assisted this type of study. Another problematic issue; is the inaccessibility of .the product of the school who produced the works. The lecturers whose inputs in the production of the art works were critical to the study were also not readily available.

However, the study surveys pottery sculpture images in Ife art school, examines the typology, form, style, theme and technique of production, and relates their importance to the Southwestern Nigeria's public environment. This study aims at bringing to fore the relevant art historical value in the practice of contemporary pottery sculpture using lfe art school's outdoor pottery sculpture display as a base to highlight its under-utilization in the Southwestern Nigerian public environment. The study operates on the following set of objectives; opening of a platform for exquisite pottery sculpture media exploration, execution and display for the public; encouraging pottery sculpture iconic, morphology and stylistic development as well as availing the public of exciting sculpture types imbued with awesome traditional flavour. Significantly, the study have rich art historical information about the practice of outdoor sculpture in Ife art school; and it hopefully should create a platform for further, research into the practice of contemporary pottery sculpture and other related areas in Nigeria. In this study, the use of public environment refers to all road intersections (round-abouts, road highlands, parks and garden) that are opened to all law abiding citizens without prejudice. Religious centres, commercial 
houses, and other public institutions are also within the framework of public environment, but they are however not within the general focus of this study. The word terracotta has also been used interchangeably because of its contiguous meaning to the definition of pottery sculpture.

\section{Methodology}

Direct field work research method has been employed for the study. The study being both art practice and historical research relied on participatory observation which provided a good opportunity to conduct oral interviews and observe pottery sculptors in the practice over a period of time. The stakeholders in the art practice were randomly selected and interviewed. Resources persons interviewed comprises of foundation lecturers and five members of staff of Ife Art School, sixteen students including the three students who produced the pottery sculptures and other ceramic students across different generations. The period of observation and systematic collection of data has been between 1982 and 2015 when the photograph of the pottery sculpture objects were sequentially taken in their various locations. However, more photographs of the art works were taken in 2014 and 2015 and data were formally processed recently. Oral evidence used in this study also includes oral tradition and the discussion was supported with relevant literature materials. The method used in the study provides excellent observation of studio practice, data collection and examination, analysed basically through qualitative with minimal quantitative approach and buoyed with descriptive mode of the art historical issues in the study.

\section{Review of Relevant Literature}

Previous publications on pottery in Nigeria are numerous and wide in topical issues on art history, theory and practice of pottery and ceramics. Cardew's (1967) scholarly study on his workshop practice in Nigeria is probably unsurpassed. In the publication, aside the theory and practical guide, painstakingly presented Ladi Kwali, an enigma in pottery, spotlighted as a genius in contemporary pottery in Nigeria that emanated from the stable of Cardew. Fatunsin (1992) discusses the Southwestern Nigeria pottery forms. She studies the morphology and analytically categories them by type and function. In the publication of Ibigbami (1981: 12-19), attention was placed on inspirations drawn by potters through ritual invocation often made to lyamopo, the Yoruba patron goddess of the pottery vocation. He discusses the general practice of the art, highlighting raw material prospecting and production techniques. He also classified pots by types. Kalilu, Akintonde and Ayodele's (2006) publication is comprehensive. It provides rich information on theory of ceramics, history of the practice in the 21st century, as well as the didactic issues arising from the relations of, and relationship between, the traditional pottery centres and tertiary institution in the Southwest of Nigeria.

The issue which Agberia and Akinbogun separately examine underscores low productivity. Akinde's (2009) work is based on generation of glaze material from fruit peels and the success of his experiment on the research was elaborately discussed. Abiodun, Akintonde and Akinde (2013: 103-111) examine the ceramic entrepreneurship in Oyo State, Nigeria. They look at the various developments of ceramic industries in the State and opined that stiff competition from cheap imported ceramic wares and non-readily availability and high cost of imported glazes as well as poor incentive in the local production of glaze products and coupled with lack of ceramic equipment became the undoing for the progress of the industry.

Fajuyigbe and Umoru-Oke (2005: 24-37) discusses pottery development in Ife art school. History of the pottery section and the unique form and style of pottery practice of the School were discussed. They observe that traditional pottery form and design require integration into modern pottery engagement in Nigeria and later highlighted the immense contribution of some potters to the development of the School.

However, the work of Ajadi (2014) is more in tandem with this current study. He examines the contribution of Ife art school to the development of ceramic in Nigeria. The study observes the Art school historically and assesses the ceramic practice. He also observes some fundamental problems in the practice of ceramics in the School. Notwithstanding, Akintonde (2013a: 136-144) is closely related in scope to Ajadi (2014), but is more comprehensive in discourse and issues relating to pedagogical problem he also addressed. Odibor (1996), Adewale (1998), Adisa (1999) and Akintonde (2008: 17-39, 2009b, and 2004: 15-27), Akintonde and Kalilu (2013: 88-103 and 2013: 26-37) have also copiously discussed various topical issues on outdoor sculptures of the Southwest of Nigeria, but none addresses pottery sculpture in the Southwest of Nigeria or elsewhere.

Nonetheless, of much significance is Oladugbagbe's (2012) study. It is a comprehensive study of garden sculpture in tertiary institutions of Nigeria. He accorded prominence to Ife art school on the discussion on trend and development of 
outdoor sculpture display on the Ife art school garden. Nonetheless, his study fails to capture pottery sculpture as an archetype deserving scholastic place in the history of garden sculpture in Nigeria. However, in all these publications and many others that were mentioned here, only the Akintonde (2009b and 2013a: 120-129) tacitly indicated deduceable information that pottery sculpture had not been part of the varied sculpture objects of public outdoor sculpture of Southwestern Nigeria that has been given any literary attention. Nonetheless, all these informative and thought provoking publications have served as good background to this study.

\section{Pottery Sculpture in Ife Art School Garden}

Clay the main material used in pottery outdoor sculpture production is in abundance virtually in all Nigerian regions. It is cheap and easy to process. It is malleable to form construction but less permanent at leather hard state. It is bristle in response to intensive impact; its form can easily disintegrate when in contact with water or high humidity. Nevertheless, only when it is technically subjected to heat by firing process to temperature between $750^{\circ} \mathrm{C}$ and $950^{\circ} \mathrm{C}$ can it be made permanent. Pottery sculpture fired to the above temperature and maintained like works made in other media will also be durable comparatively. For instance, many of the Ife terracotta figures excavated by Peter Garlake (1977: 59-95) and Omotoso Eluyemi (1978) were fairly intact in form after being buried for hundreds of years. This level of permanency makes clay a valuable material for outdoor pottery sculpture. The uniqueness of the medium, both in durability and versatility has been well explored by the Ife art school potters.

So far, thirty five substantial pottery sculpture objects made between 1983 and 1994 in Ife art school have been identified. Ten of the works were actually erected outdoor in the main sculpture garden of the school at one time or the other. Only three of the works are still in the garden since 1989, one of the works was mounted on a low wall of the sculpture studio since fourteen years ago. Others are Yemoja and Oge (plates 3 and 4) that were on display in the garden between 1984 and 1985 before they were kept indoor. A o merin joba of Akintonde (plate 5) was displayed outdoor for less than three months in 1984. The triumph of Ogun (plate 6) was displayed in the garden briefly in 1988 before it was relocated to floor "O" in the Senate Building of Obafemi Awolowo University sixteen years ago. Okunade's $A$ o merin joba (plate 7) and Bamu bamu la yo (plate 8) were also in the garden between 1997 and 2006. Oduduwa produced by Nasiru (plate 9) was also located in the garden since 1989 and relocated to the department gallery in 2006. Nwogu's Flutist (plate 10) is currently on display indoor at the main entrance of the lfe Art School. A number of the pottery sculpture works in the garden improperly erected fell during rain storms while few were accidentally broken by spectators because they were erected on low pedestals. It was for these reasons that some pottery sculptures have been kept on display at the Department's gallery. Apart from those on display at Ife art school, two works made by Akintonde in 1984 were acquired by the Nigeria Art Council and National Commission for Museum and Monument in 1984 during the Tenth Year Anniversary of Ife School of Art, commemorated with an art exhibition held in Lagos. One of them, the Cockrel Wall Fountain was erected at the courtyard of the National Art Council, while the Olojo festival was mounted on the walls of the National Commission for Museum and Monument, Lagos around 1985.
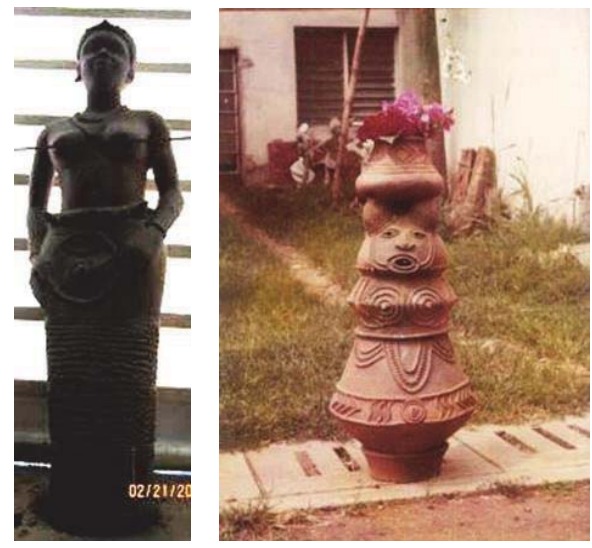

Plate 3: Moses Akintonde, Yemoja (Water Goddess), Terracotta, 1983. Photograph by Ajadi Micheal 2012

Plate 4: Moses Akintonde, Oge, Terracotta, 1982. Photograph by Moses Akintonde 1984 

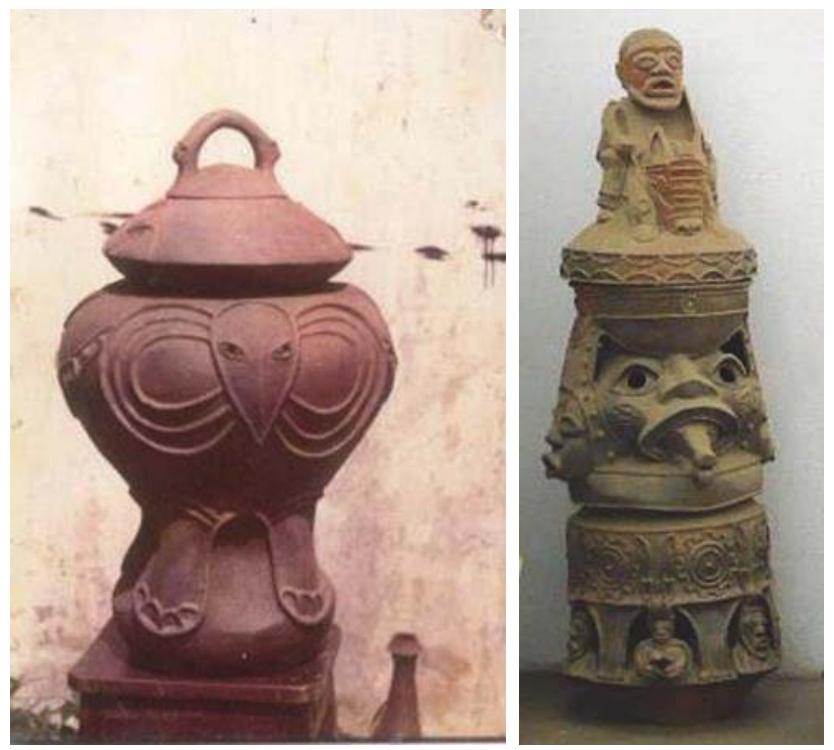

Plate 5: Moses Akintonde, A o merin joba, Terracotta, 1983. Photograph by Moses Akintonde 1984. Plate 6: NasiruBabatunde, Triumph of Ogun, Terracotta, 1987. Photograph by Yinka Okunade, 2015.
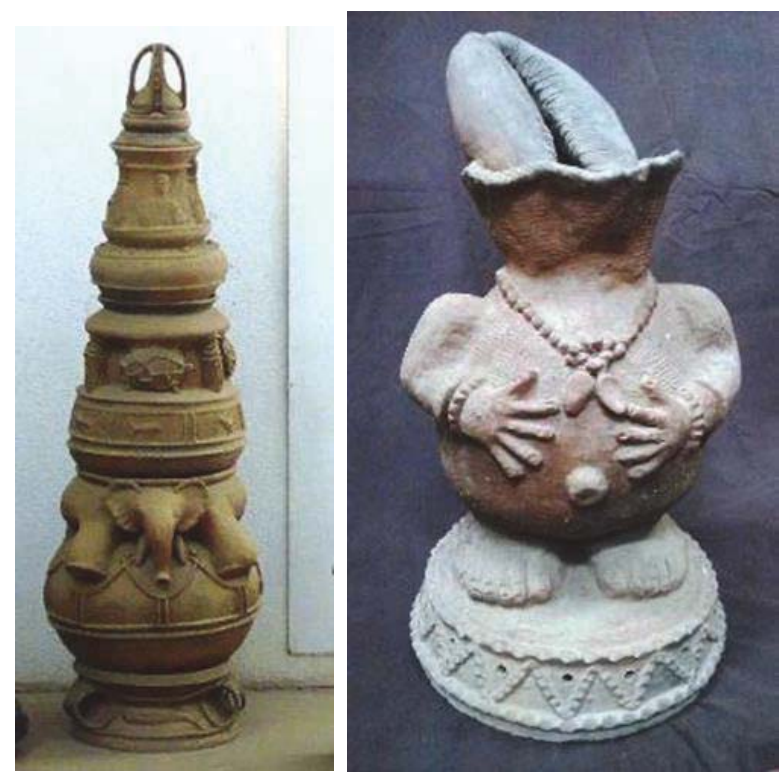

Plate 7: Yinka Okunade, A o merin joba, Terracotta, Photograph by Yinka Okunade, 2015.

Plate 8: Yinka Okunade, Bamu Bamu layo, Terracotta, 1989. Photograph by Yinka Okunade, 2015. 

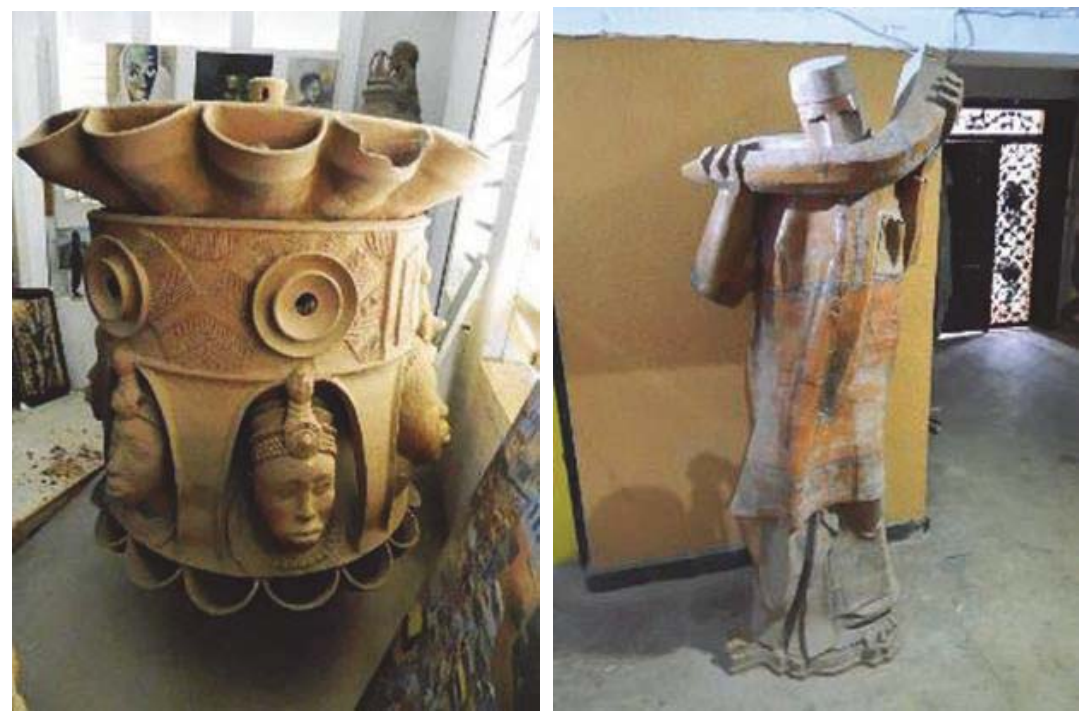

Plate 9: Tunde Nasiru, Oduduwa, Terracotta, 1987. Photograph by Yinka Okunade, 2015

Plate 10: Nwogu, Flutist, Terracotta, Photograph by Yinka Okunade, 2015.

\section{Technique of Production of 'Ife' Pottery Sculpture}

The clay used in Ife Art School for pottery sculpture production usually mixed empirically with addition of about 20 percent of grog, 10 percent of sand and 5 percent of small stone and 65 per cent of clay for good strength and hardness. Although, pottery sculpture generally employs additive and subtractive or subtractive methods of form construction, these methods are also combined and more technically handled in the pottery sculpture than other sculpture types because of the fragile nature of the medium and the processes involved.

In the free standing pottery sculpture, form were usually first built into solid basic form of intended work and left for about twelve hours or more, depending on the size of the work and humidity level to set (become hardened). Later the solid work was carefully cut into halves and gradually hollowed into a regular thin walls of about $10 \mathrm{~mm}$ thickness and joined, after which all necessary details were skillfully worked in. Sometimes, big work or delicate form that cannot stand on its own, were cut into sections, hollowed and joined. Nwogu's work (plate 10) was made in this way. In fact, the work was carefully cut into twelve units taking cognizance of the intricacies such as the undercuts and the extremities, so as not to alter their forms. The pieces fired separately and latter bonded with ponal glue (a common brand of adhesive) mixed with required measure of grog for good bond and hardness. The terracotta relief pieces, Olojo festival, and Sango (plate 11) produced by Akintonde and the A o merin joba (plate 12) version of Okunade were also made in the same way. Other pottery sculptures were moulded directly on pot pre-made with coil method (plates 7). Sometimes, figurines were moulded in solid form and attached to the walls of pots (plate 3). Pottery sculpture objects were fired in traditional open kiln (plate 13) for four hours with temperature ranges of $750^{\circ} \mathrm{C}$ and $900^{\circ} \mathrm{C}$. The temperatures were sufficient for earthenware clay body vitrification and good quality strength. Apart from Nwogu's flutist (plate 10) that was laminated with wood vanish, no other work was given special surface treatment; all the works were specifically left in their natural terracotta effect state. 


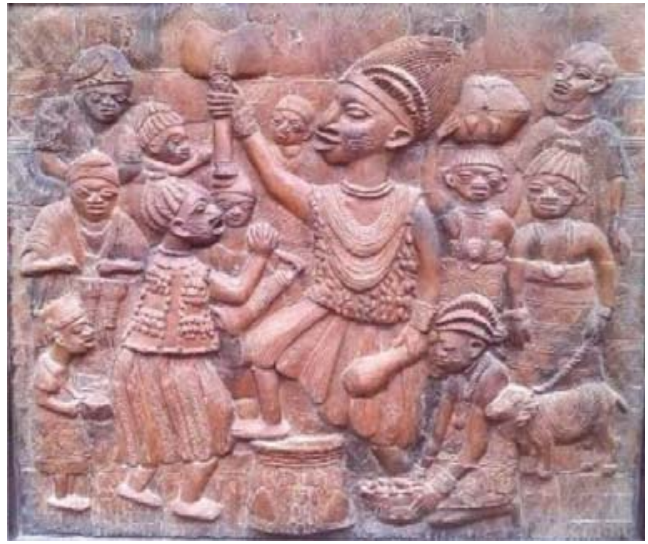

Plate 11: Moses Akintonde, Sango, Terracotta, 1982. Photograph by Moses Akintonde 2015

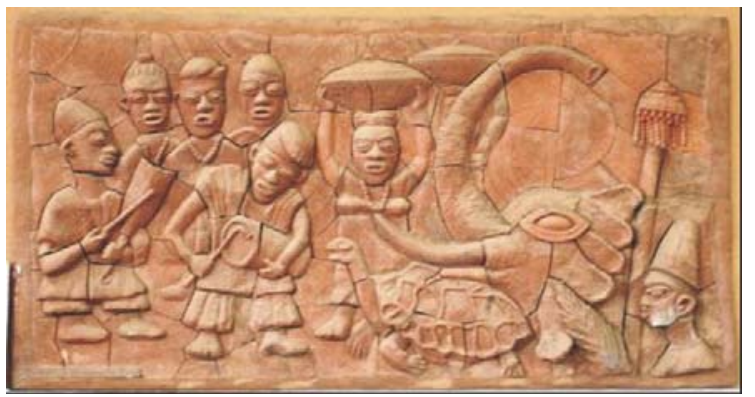

Plate 12: Yinka Okunade, A o merin joba, Terracotta, 1995. Photograph by Yinka Okunade, 2015

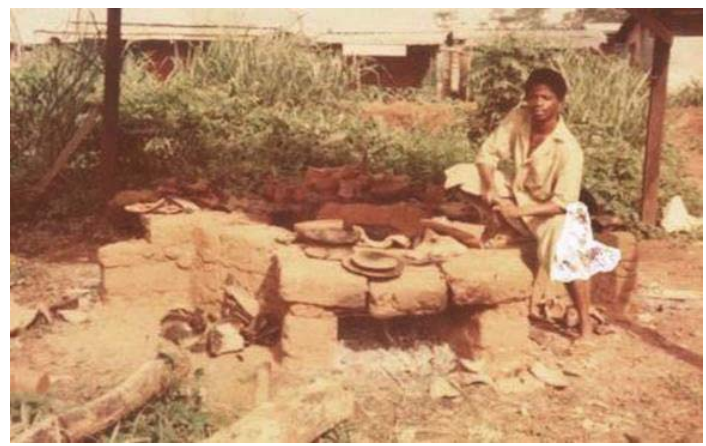

Plate 13: Moses Akintonde at traditional open kiln of Fine Art Department, University of Ife (now Obafemi Awolowo University), Ile-Ife in 1984. Courtesy: Moses Akintonde 2015.

\section{Pottery Sculpture Archetypes and their Traditional Yoruba Contextual Tendencies}

It is very difficult to classify the types and the unique heterogeneous forms of Ife art school pottery sculpture. But certainly, they present a pleasurable phenomenon in outdoor sculpture practice and its position in art historical engagement. Nevertheless, an attempt will be made to classify them. The ceramic sculpture of the school can be classified by forms into three types. First is the free standing sculpture or sculpture in the round (plate 10); the relief 
images (plates 11 and 12) is the second type. The third group of pottery sculpture is basically rotund pots with superimposed figures and relief decorative motifs (plates 6 and 7). The images are expressed in realism and naturalism forms. All the groups of pottery sculpture object were technically designed to meet required expressions, in form construction and finishing. Generally, the forms of the sculpture images are biomorphic, zoomorphic and anthropomorphic. Forms were carefully woven symbolically, expressing man-animal interaction in the Yoruba cosmocelestial experience. Pottery sculptures in Ife were eximious, grandeur in flavour of the form type in Yoruba traditional carving and also laced with contemporary thought. The sculptures provoked scenic sense, invoked sensual appeals, hinged on spiritual extempore. These invariably typified the uniqueness of Ife art school which also underscored the extra-ordinary pottery sculpture forms used for outdoor display in the institution's environment.

\subsection{Examination of the pottery sculpture}

For a better understanding of the pottery sculpture of Ife art school, it is imperative to appraise the contributions of the ceramic lecturer Raphel Ige Ibigbami and the three students who produced the larger number of the outdoor sculptures. The school's conceptual choice and use of motif in designs were hoisted in the pedagogical approach of Ibigbami in pottery. He is a well breed Yoruba, versed in, and passionate about indigenous cultures. This guided him to lay the foundation of the ceramic section of Ife art school on strict adherence to African cultural elements adaptation and assimilation.

In the pursuance of the idea, he encouraged the Department to employ a local potter by name Felicia Adepelu who was to be in residence. Adepelu's execution of traditional pottery and display of dexterity influenced students in the ceramics unit of the Department. Her pottery usually was conceptually potent and replete with imagery. It largely betrayed Yoruba sculptural inclinations. So profusely used were her pains taking intricate coil designs and sculptural images that their diffusion into other art sections could vividly be discernable (plates 2). The onerous effort of Ibigbami, coupled with the university's ideology and motto 'For learning and Culture', was inadvertently employed for the advancement of sound education with cultural connection to build artist of rare knowledge, guided by humility and functional service as entrenched in African tradition. The philosophy genuinely facilitated the art students' assimilation of cultural values in the works of Adepelu (plate 2) and Lamidi Fakeye (plate 14), a neo-traditional wood carver also in residence. Enthused by culture induced pedagogy, resiliently practiced in the face of fleeting Western acculturation, many students across generational divides gradually walked through the cultural maze and raised the unique style of Ife art school upon high pedestal.

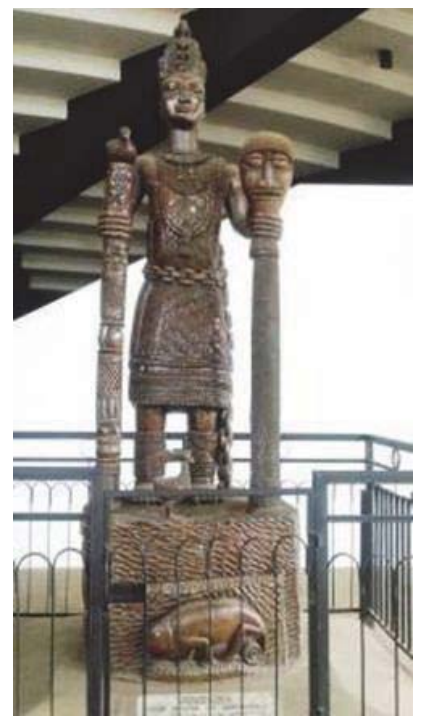

Plate 14: Lamidi Fakeye, Oduduwa, wood, Oduduwa Hall, Obafemi Awolowo University, Ile-lfe. Photograph by Yinka Okunade, 2015. 
Ibigbami's synthesis of cultural forms and contemporary idea experimentation in ceramic became a fertile ground for epochal development in pottery of the School. Earliest epoch being the period of assimilation and integration of traditional pottery forms into modern ceramic practice. Sherinatu Fafunwa and Hazel Rotimi were the fore-runners of this period. The period of profuse decoration of pottery object was between 1978 and 1982 which was still inspired by traditional forms integration with Opeyemi Arije becoming the precursor. Ibrahim Banjoko and Chris Akobudu also belong to this group but advanced more in the sculptural approach to their pottery works. Akintonde was the trail-blazer of the third epoch; closely followed by super imposing status of Babatunde Nasiru and their offspring, Yinka Okunade. These last three potters were the face of the accellerated pottery sculpture periods. The period beginning from 1983 and to 1997 was outstanding in the production of highly sophisticated, non-conventional pottery sculptures. The artists who started the experiment in the use of pottery sculpture for outdoor display is Akintonde. Nasiru, his immediate junior, also a pottery sculpture specialist, took his creativity and competence beyond the limits of Akintonde. His works were clear evidence of deep contemplation in character and deft in inspirational generation. Yinka Okunade, a pupil of Akintonde and Nasiru at different times, both at College of Education and undergraduate and postgraduate levels respectively, also benefitted from the Yoruba traditional form adaptation for pottery sculpture. The pottery sculpture images of the three artists under discussion here were the summation and the apotheosis of the outdoor pottery sculpture of Ife art school and by extension those found in the Southwestern Nigeria.

Moses Akintonde: He had initially intended to specialise in sculpture but was persuaded by lbigbami his lecturer, to specialise in ceramics. However, he apparently skewed his pottery style towards pottery sculpture with intent to explore sculptural forms. Coupled with this, was his background knowledge in the traditional Yoruba wood and stone carvings as well as bronze casting acquired during his apprentice period between 1977 and 1980 in lle-lfe under Ben Oluyemi, a wood and stone carver and Lamidi Oke, a traditional bronze caster. The training provided a good platform for Akintonde's expression in sculpture. With this experience and having been inspired by the ancient pottery sculpture forms of Ife, the works of Banjoko and Akobudu his seniors in 1981 to 1983 and buoyed also by the Head of Department, Babatunde Lawal's advise for him on trans-cultural form blending and adaptation, particularly of Dakakari pottery images; his knowledge was further reinforced in pottery sculptural form. He, however, stretched sculptural forms in pottery beyond his predecessors in the School. The result of his experiment was deft and stupendous. He was instantaneously identified with traditional Yoruba folkloric images always expressed in his pottery.

In 1983, Akintonde designed and produced a pottery sculpture adapted from Dakakari pottery form. This image titled Oge (plate 4) was in contrast to the conventional pottery forms in the Department in shape, which were normally built in traditional Yoruba pottery form with figurine appendage. However, the whole form of Akintonde's pottery experiment, were moulded in coil method into segmented human form, with head, chest and abdomen regions built separately and superimposed accordingly on each other. Coil was used to define the facial structure. The hands, breast and the navel were treated in the same vein. The image, though real to some extent, it is incongruous to normal human anatomy which was not strictly targeted by the artist. The success of the experiment, spurred Akintonde to produce $A 0$ merin joba (plate 5), the first of the series in the School. The form of the pot was made carefully to correspond morphologically to elephant voluptuous body mass. The use of relief linear definition according to Ajadi (2014) conformed better anatomically than the Oge (plate 4). In finishing Akintonde's works are serene and sensual. In fact the Yemoja (plate 3), figural sculpture aptly described Akintonde resolve for serenity, luxuriant and sensual surface treatment. Here, the mastery of naturalism was attempted and made plausible with the thematic expression of Yemoja whose mythical beauty and horrendous smile is captivating as bait to her victims.

Babatunde Nasiru: Nasiru whose specialization in Master of Fine Arts (MFA) is pottery sculpture is highly potent in concept development, dexterous in pottery form creation and expression. His morphological interpretation and graphical expression of idea is breadth taking and deep in fantasy, yet realistic in taught and ecstatic in aesthetic pleasantry. The forms, of his works (plates 6 and 9) were usually arranged in segmented pictorial sequence. The base, the load bearing is stout and broad. It is a part of the composition rather than mere pedestal from where the pot grows in tubular or spherical formation toward the middle part and tapper immediately to the apex. On this rotund form are the figurine appendages and at the apex a free-standing image crowned the entire pottery form.

The concept of his expression can vividly be visually decoded and lexically interpreted right from the crest of the form, reeling out in scenic pictorial format. In Nasiru's Triumph of Ogun (plate 6), a thematic similitude of both the spiritual and physical ambivalent and umbrageous acts of Ogun in the Yoruba cosmogony is brought to light. The gallantry of Ogun in wars against his detractors and his beneficial force in bountiful agricultural harvest in the use of iron its symbol for farm implements were formalistically encoded. Ogun's invocative and divine blessing upon all human endeavours particularly, where the use of iron is primarily necessary, were also conceptually expressed in the triumphant equestrian 
figure atop the fourth segment of the pot. Ogun who is one of the pantheons of Yoruba gods is aggressive and highly temperamental but benevolent to his devotees-swift and fierce in actions against criminals, nonetheless, he is righteous in judgment. Ogun was captured here in one of his earthly escapades. Gant, focused and majestic; he was represented gallantly riding a well decorated horse peculiar to the Yoruba warlords, similarly represented in Yoruba wood carving and royal veranda posts (plates 15 and 16).
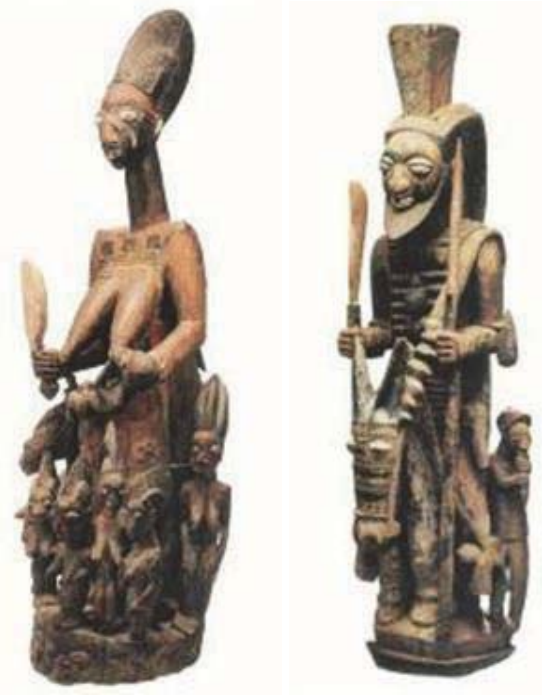

Plate 15: Olowe of Ise, Female equestrian surrounded by seven figure, wood, pigment, 1938. (Adele, 1998: 65)

Plate 16: Olowe of Ise, Royal veranda post, wood, pigment, c. 1910-14. (Adele, 1998: 83)

On the second segment is the super imposing image, a representation of the fierce expression of Ogun. The whole image is voluminous, wired in the expression of the budging mystical eyes; which appears to be scanning the mundane activities. The image's broad nose probably stimulates a pulsating awesome breadth of power and agility. The expressions of gaping mouth and protruding tongue are also an open display of power. Although the masklike image appear fearful, it is however, not meant to scare people but rather to express Ogun's sacred power and authority among the Yoruba pantheon of god's. This of course is a warning sign to careless devotee, non-initiates and criminals.

The third segment of the pot is divided into two. Its lower part has a porch designed in the form of Yoruba palace veranda arch. In the porch are skemorphic human anecdotal figures. The upper part of the segment has linear decoration of concentric circle in relief design but the forth segment of the pot is the sparsely decorated base.

The form and style employed to produce Ogun and other works by Nasiru are similar. However the grandeur and the finesse in the form building and composition of Sango (plate 17) produced in 1988 is unique. Although, segmented like the other previous pottery sculpture of Nasiru, it appears a one whole piece; much typical of the Yoruba traditional carving. The Sango symbolic hairdo at the crest of the superstructure is nothing but wood carving in outlook. The whole structure is very close in form to Fakeye's Oduduwa image (plate 14) erected at the basement of Oduduwa Hall, Obafemi Awolowo University, lle-lfe.

In Nasiru's Ara Orun (plate 18), the porch and the arch and the catayard made in the manner of Yoruba veranda post are now becoming more typical of his "signature" it appears in many of his works. But the porch here was irregular unlike the graphical presentation of its archetypes in the triumph of Ogun (plate 6) and Oduduwa (plate 9). His Ara orun appears more decorative and lacking in terms of form and the dexterity he displayed in triumphant of Ogun (plate 6), Oduduwa (plate 9) and Sango (plate 17). Nasiru apparently used the ancient Owo terracotta motif in his Ara orun image. 

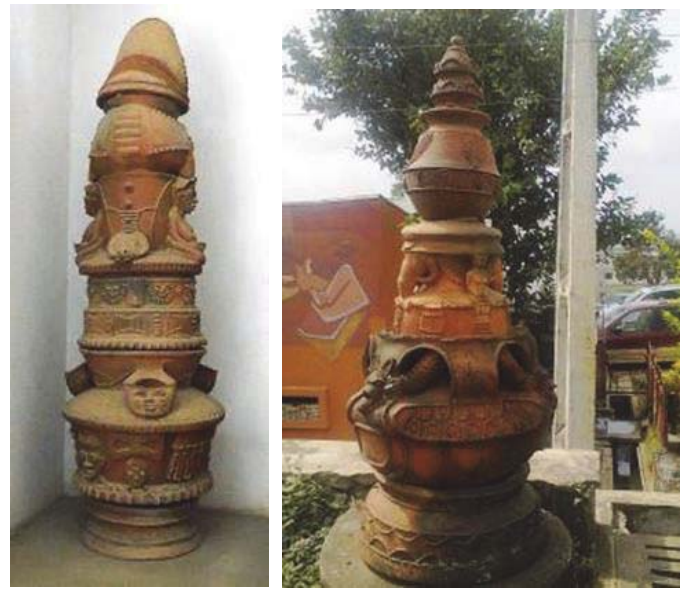

Plate 17: Tunde Nasiru, Sango, Terracotta, 1988. Photograph by Yinka Okunade, 2015

Plate 18: Tunde Nasiru, Ara Orun, Terracotta, 1988. (The top segment of the pot shown above is an addition from another artist after the original has broken). Photograph by Segun Abiodun, 2014

Perhaps, it is in Nasiru's Sango relief terracotta sculpture (plate 19), one can appreciate more stimulating impulse in clinical finishing of his three dimensional pottery sculpture images. His relief sculpture appeared deliberately simplified and raw in finishing, yet the spiritual aura that pervaded and drenched the whole scene is a unique taste of aesthetic soundness, marked by Nasiru's originality in form invention. Here, it appeared he pulled himself away from the polished finishing format of Akintonde (plate 11).

In the composition of Sango relief (plate 19), Nasiru's expression of frontality in of forms removed the problem of perspective which Akintonde tried to solve in his Sango (plate 11). Here, Nasiru relieved himself of linear perspective and adapted hierarchical perspective placing more emphasis on the leading subject. In the composition, the central figure was shifted a little bit from the middle of the panel, so as not to unwittingly divide the composition into two halves. All other figures were arranged hierarchically. The forms were clearly defined. All Sango costume, Waba (thw skirt) and Laba (vest), the hairdo and the paraphernalia were expressed vividly emblematic and symbolic of the god. The paraphernalia of Sango, the dancing wand (Ose Sango) and rattle gourd (Sere) were held by Sango and the devotees in various ways, typically in genuflect. Of course, there is the Sango mortal (Odo), centrally placed; representing power and authority of Sango. On the Sango mortar is a zoomorphic figure- the wall gecko (tewogbeji). This image is symbolic in Yoruba mythology. It is an instrument of Sango who is associated with thunder, lightning and making of rain. If Sango would make rain, he would send tewogbeji to open its hands. Once this was done, heavy down pour was assured.

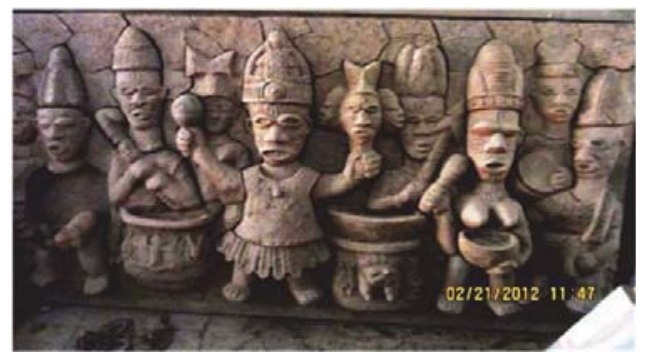

Plate 19: Tunde Nasiru, Sango relief sculpture, Terracotta, 1987. Photograph by Ajadi Micheal, 2012

Yinka Okunade: Design format in composition, form building choice and use of motifs and style of expression as well as conceptual basics and thematic ordering of pottery sculpture conformed with the works of Akintonde and Nasiru. However, Okunade differs in narrative power. In the Okunade's A o merin joba free standing figure (plate 7) he delved 
into a popular Yoruba folklore. Thematically, the content of the pottery sculpture expresses well, the golden rule in the idiomatic expression-look before you leap, a similitude of Yoruba moon-light story type. The free standing pottery sculpture is a five segment pot. The major expressions in a scenic bas relief on the rotund form spot-light the greedy and careless elephant acceptance of spurious offer to rule over the human kingdom. The elephant, an animal (sometimes ascribed human roles in Yoruba folklore), demonstrated its naivity to believe in its widest imagination that the sophisticated human being will stooped so low to accepting animal leadership of man. It is a biezzer and unfathomable phenomenal. In the metaphor, the foolish elephant fell into the smear of grand plot of the higher brains who used it for their spiritual gain.

The layout of the form and the surface treatment is closely related to traditional Yoruba wood carving forms. The forms are lucid in expression and easily read. Okunade started the narration of the story in a pictorial form, from the top of the sculpture and concluded it at the bottom, dragging his audience into the art, to observe with rapt attention. His ingenuous power of narration with convenience perhaps distinguished him of the trio. For instance, the pottery sculpture first expressed in the same theme in the school and titled A o merin joba was (plate 5) produced by Akintonde in 1983. It was expressed in one whole form. Although, simple in morphological built and iconic representation, it is more instamatic in decoding the encoded meaning. It is however, not engrossing for audience when accessing its aesthetics value as that of Okunade. Okunade's dexterity of story narration was vividly presented again in the relief pottery sculpture with same title, A o merin joba (plate 12). Again, Okunade seemed to ushered into the stage from the right side panel, the principal actors of the story. The elephant being the leading subject matter of the narrative is larger than other figures and accorded prominent space; represented trumpeting vigorously in power play. It was lead by the tricks star, the tortoise that calculatively walks carefully in derision of the foolish elephant. Maiden gifts bearers and drummers and spectators who deceiffully cheers elephant to his death were represented in the background according to their hierarchical order. The narration here seem to be the metaphor of the image of typical Nigerian politicians whose lean popularity cannot win election ticket, yet, yielded themselves to be cajoled, hoodwinked and fleeced of their wealth only to be slaughtered on the slab of ballot boxes.

In summary, these three artists among the Ife art school artists have been identified to have displayed gracious dexterity in execution of pottery sculpture art form. Their successors in the school lost the driving steam in the Africaness concept in art strictly practiced from 1980 until early 90s. From this period onward, pottery art expression became individualistic and free choice of an intense hybrid of "Western-Niger" culture of anything goes in art expression gained current. Imported toy cars, flower and other Western objects forms began to creep into the expression of pottery sculpture in the school. All through, the remaining half of 90 s, expression in pottery sculpture was greatly affected by the WesternNigeria cultural adulteration. Pottery sculpture forms were hardly addressed towards strict traditional Yoruba or Nigeria cultural identity as hitherto encouraged by the motto of the school. With the advent of the new millennium, expression in pottery sculpture became more severe in individualistic modern forms and styles (plates 19 and 20) very limited in size unlike the earlier Ife art school-giant size pots; and almost severing the remaining fragile ties with the renowned Ife art school unique traditional form and style. As a result of this pottery sculpture uses for outdoor display at Ife school of art greatly declined. Other arts schools that had imbibed Ife art style also capitulated from the style in the same manner.

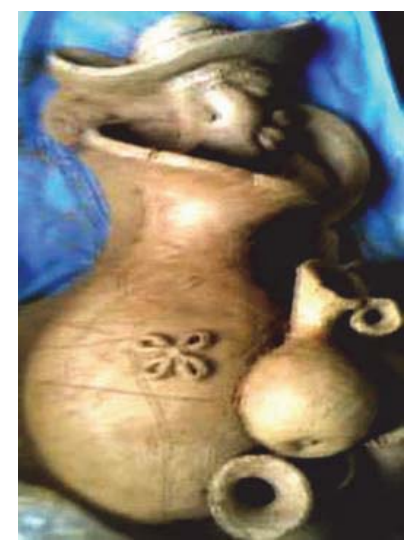

Plate 19: Olusegun Fajuyigbe, Palm Wine Tapper, Terracotta, 2011. Photograph by Ajadi Micheal 2012 


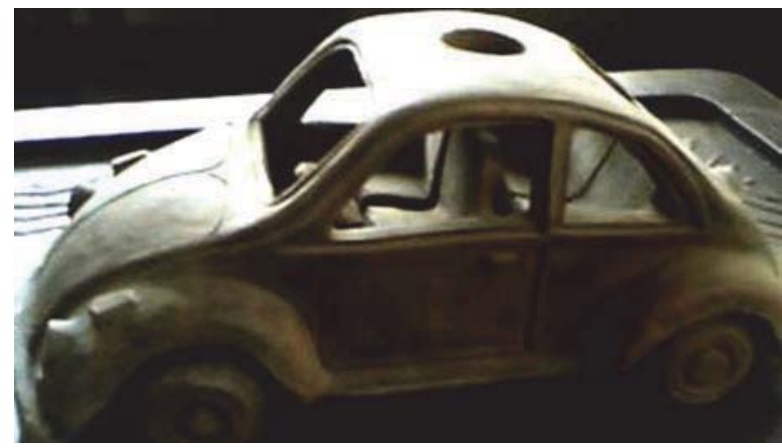

Plate 20: Oladejo Abraham, ljapa, Terracotta, 2 by 1 feet, 2001. Photograph by Ajadi Micheal 2012

\section{Conclusion}

Pottery sculpture which has been part of the rich Nigeria art tradition since the ancient time has yielded a phenomenal art historical information about different Nigerian cultures. From the rich finds of Nok, Ife and Owo pottery sculpture traditions, a vent was opened to view the people's cosmic world in the belief system. The works which have provided continual services for the religion of the people apt also indicate their socio-economic direction. But more important are the conceptualization in thematically expression and the formal quality of the art which tend to give direction to the extant outdoor pottery sculpture practice of Ife art school. The ancient art bequeathed a source of inspiration for the modern day pottery sculpture of Ife art school students who studied the works and adapted forms, suitable for the present aesthetic need from them. Although, their pottery sculpture expression might not be like a conventional Asiatic human expression of the Chinese army terracotta (plate 21) or a Western outdoor sculpture figure format, the pot-like sculpture, provide a completely new genre in the field of outdoor sculpture in Nigeria and perhaps the world over. This contribution to art is unique; it is an identity of a Nigerian art, a typical renaissance of the ancient Ife art combined with the traditional Yoruba wood carving forms and finishing, formalistic and stylistic tenderness, often spiced with fecundious Yoruba folkloric themes.

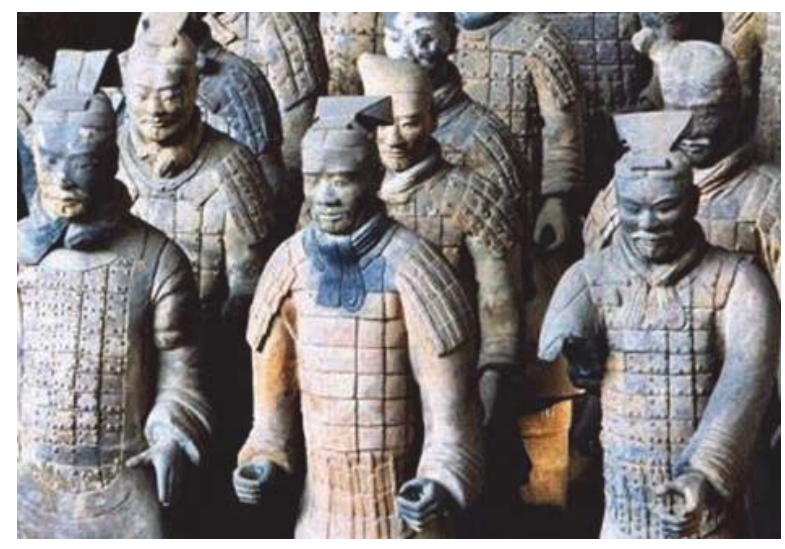

Plate 21: Terracotta Chinese Army

(www.smithsonianmag.com/history/terra-cotta-soldiers-on-the-march-30942673/)

The use of the rarefied pottery sculpture type for outdoor sculpture is quit new in art historical discussion in Nigeria. This publication is perhaps the first to put the work in art historical perspective. More so, that in all outdoor sculpture of the Southwestern Nigeria, non like the pottery sculpture archetype of Ife art school were found among them. The works and the uses for outdoor sculpture will likely elicit more analytical art historical and studio practice discussions in future. 


\section{References}

Abiodun, S. O, Akintonde, M. A. and Akinde, T. E. (2013). Small Scale Ceramic Industry in Oyo State: Challenges and Prospects. Journal of Economics and Sustainable Development. 4(11): 103 -111.

Adelowo, G. (1999). Outdoor Sculpture in Ibadan Metropolis. M. A. Dissertation in Visual Art History, Institute of African Studies, University of Ibadan. Ibadan, Nigeria.

Agberia, J. T. (1998). Ceramic Industry in Nigeria. USO: Nigerian Journal of Arts. 2(1 and 2): 66-72

Ajadi, M. O. (2014). Contributions of Ife Art School to the Field of Ceramics. M.Tech. Thesis in Department of Fine and Applied Arts, Ladoke Akintola University of Technology. Ogbomoso, Nigeria.

Akinde, T. E. (2009). Fruit Peelings as Ash Glazes. M. Tech. Thesis in Department of Fine and Applied Arts, Ladoke Akintola University of Technology. Ogbomoso, Nigeria.

Akinbogun, T. L. (2004). The State of Small Scale Ceramic Industry in Southwestern Nigeria. Doctoral Dissertation, Department of Industrial Design, Federal University of Technology, Akure. Akure, Nigeria.

Akindele, A. O. and Makinde, S. A. (2005). Four New Heir of Onaism: Their lives, works and Influences. In P. S. O. Aremu, Babasehinde et.al. (eds), Contemporary Issues in Nigerian Art: Its History and Education,. Ile-Ife, Department of Fine and Applied Arts, Obafemi Awolowo University with the support of Nigerian Gallery of Art.

Akintonde, M. A. (2004). Outdoor Sculpture in Osun State: Emergence and Development. International Journal of African Culture and Idea (IJACI). (4)6: 15-27.

Akintonde, M. A. (2008). Decadence in Southwestern Nigerian Urban Sculpture Practice. Ela: Journal of African Studies. 23 and 24: 1739.

Akintonde, M. A. (2009a). Trends in Ritual Pottery Practice in lle-Ife. Journal of Visual Arts. 1(2): 95-108.

Akintonde, M. A. (2009b). Outdoor Sculpture in Southwestern Nigeria 1900-2005: A Survey of Attitudes. Doctoral Thesis, Department of Fine and Applied Arts, Ladoke Akintola University of Technology. Ogbomoso, Nigeria

Akintonde, M. A. and Kalilu R. O. R. (2013). Emergence and Development of Outdoor Sculpture in Southwestern Nigeria. Journal of Arts and Humanities. 2(5): 88-103.

Akintonde, M. A. (2013a) Typology and Geography of Outdoor Sculpture in Southwestern Nigeria. Research on Humanities and Social Sciences. 3(10): $120-129$.

Akintonde, M. A. (2013b), Repositioning Ceramic Professionalism in Art Training in Nigeria. Journal of Education and Practice. 4(16): $136-144$.

Cadew, M. (1967). Pioneer Pottery. London: Longman.

Eluyemi, O. (1978). The Living Art and Craft of Ile-Ife. Ile-Ife: Adesanmi Printing Works.

Eyo, E. and Willett, F. (1980). Treasure of Nigeria. New York.

Eyo, E. (1990). Two Thousand Years of Nigeria Art. London: Ethnographical in Association with National Commission for Museum and Monuments, Lagos.

Fatunsin, A. K. (1992). Yoruba Pottery. Lagos: National Commission for Museum and Monuments.

Fagg, W. (1990). Nigerian Images. Lagos: National Commission for Museum and Monuments.

Fajuyigbe, M. O. and Umoru-Oke, N. (2005). The Influence of Pottery Tradition of the Department of Fine Arts, Obafemi Awolowo University, Ile-Ife: Development, Techniques and Innovation. In Aremu, P. S. O., Babasehinde et.al. (eds), Contemporary Issues in Nigerian Art: Its History and Education. Ile-Ife, Department of Fine and Applied Arts, Obafemi Awolowo University with the support of Nigerian Gallery of Art.

Garlake, P. (1977). Excavations on the Woye Asiri Family-land in Ife Western Nigeria. West African Journal of Archaeology. 7. pp. 5995.

Ibigbami, R. I. (1981). Traditional Pottery in Yoruba Culture. Black Orpheus. 4(1): 12-19.

Kalilu, R. O. Rom, Akintonde, M. and Ayodele, O. (2006). Ceramics: Art and Technology in the 21st Century Southwestern Nigeria. Agege, Lagos: Pemilter.

Kashim, I. B. (2006). Arts and Technology: Enterprising skill Acquisition Though Industrial Ceramics Training in the Federal University of Technology, Akure. In Filani, K, Azeez, W. A., Onipede, A. O. and Ademuleya, S. (eds.) Potential of Visual Arts and Creative Industry in Africa. Lagos: CCAF. pp. 115-123.

Oladugbagbe, F. E. A. (2012) Stylistic and Thematic Development of Garden Sculpture in Nigerian Art Institutions (1970-2000). Doctoral Thesis, Department of Fine and Applied Arts, Ladoke Akintola University of Technology, Ogbomoso, Nigeria.

Odiboh, F. (1987). Outdoor Sculpture in Lagos Metropolis. M. A. Dissertation in Visual Art History, Institute of African Studies, University of Ibadan. Ibadan, Nigeria.

Rhodes, D. (1998). Clay and Glazes for the Potter. London: Krause

Walker, R. A. (1998). Olowe of Ise Ekiti: A Yoruba Sculptor to the King. Washington D.C.: National Museum of African Art, Smithsonia Institute

Willett, F. (1973). Archaeology, Sources of Yoruba History. Biobaku S. O. (ed). Oxford: Clarendon: 111-139. 